\title{
Hubungan Kebisingan dan Masa Kerja terhadap Jenis Ketulian dan Stress pada Pekerja PT. Semen Tonasa
}

\author{
Rezky Putri Indarwati Abdullah*, Sigit Dwi Pramono², Ida Putri Ihsani \\ ${ }^{1}$ Depertemen Ilmu Kesehatan Masyarakat, Fakultas Kedokteran, Universitas Muslim Indonesia, Kota Makassar, \\ Indonesia \\ ${ }^{2,3}$ Depertemen Biokimia, Fakultas Kedokteran, Universitas Muslim Indonesia, Kota Makassar, Indonesia \\ *Email Korespondensi: rezkyputri.abdullah@umi.ac.id, Telp: 085242632368
}

\begin{abstract}
ABSTRAK
Latar Belakang: Kemajuan teknologi sektor industri, telah menciptakan macam produk mesin yang seringkali menghasilkan timbulnya bising di tempat kerja. Gangguan pendengaran disebabkan beberapa faktor diantaranya: umur, intensitas bising, masa kerja, lama kerja dan penggunaan Advanced Package Tool (APT). Maka dari itu penelitian ini ingin mengetahui hubungan kebisingan dan masa kerja terhadap jenis ketulian dan stres pada pekerja. Metode: Penelitian ini adalah analisis observasional dengan metode cross-sectional. Sampel dalam penelitian ini adalah pekerja pabrik PT. Semen Tonasa yang berjumlah 82 orang. Teknik sampling yang digunakan adalah purposive sampling. Teknik pengumpulan data dengan wawancara melalui kuesioner dan pengukuran intensitas kebisingan dengan Sound Level Meter serta data rekam medik.

Hasil: Penelitian menunjukkan dari 82 responden, didapatkan yang bekerja pada area bising $<80 \mathrm{~dB}$ yaitu 30 orang, Yang bekerja pada area bising $80-100 \mathrm{~dB}$ yaitu 10 orang dan yang bekerja pada area bising $>100 \mathrm{~dB}$ yaitu 42 orang. Kemudian didapatkan 30 orang diantaranya memiliki hasil pemeriksaan audiometri normal, 28 orang NIHL, 20 orang BCHL dan 4 orang campuran. Pada pekerja berusia 20-30 tahun yaitu 22 orang, berusia 31-40 tahun 17 sampel, berusia 41-50- tahun yaitu 33 sampel dan berusia $>51$ tahun yaitu 10 orang. Pada pekerja dengan masa kerja lebih dari 5 tahun yaitu 76 sampel dan 6 sampel dengan masa kerja $\leq 5$ tahun. Pada pekerja tidak stres 30 orang, stres ringan 12 orang, stres sedang 18 orang dan stres berat 22 orang.

Kesimpulan: Derajat kebisingan memiliki hubungan signifikan dengan stres. Sedangkan tidak didapatkan hubungan antara masa kerja terhadap jenis ketulian. Masa kerja juga tidak memiliki hubungan signifikan terhadap stres.
\end{abstract}

Kata kunci: Kebising; jenis ketulian; masa kerja; stres

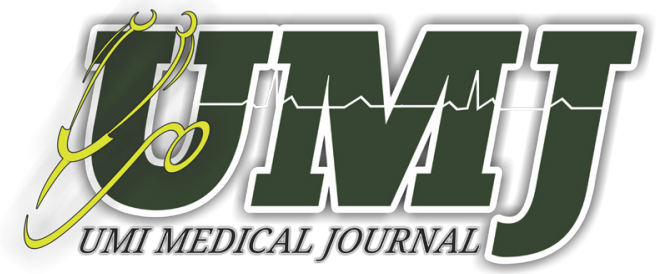

Article history:

Received: 1 May 2020

Accepted: 23 June 2020

Publish Online: 30 June 2020

Published By :

Fakultas Kedokteran

Universitas Muslim Indonesia

Phone:

+6282293330302
Address:

Jl. Urip Sumoharjo Km. 5 (Kampus II UMI)

Makassar, Sulawesi Selatan.

Email:

medicaljournal@umi.ac.id 


\begin{abstract}
Background: Technological advancements in the industrial sector, have created a variety of machine products that often produce workplace noise. Hearing loss is caused by several factors including age, noise intensity, length of work, length of work and use of APT. Knowing the relationship of noise and work life to the type of deafness and stress in workers.

Method: This study was an observational analysis with a cross-sectional method. The sample in this study were factory workers at PT. Semen Tonasa, amounting to 82 people. The sampling technique used was purposive sampling. Data collection techniques through interviews through questionnaires and measurement of noise intensity with Sound Level Meters and medical record data. Collecting sample data in accordance with inclusion criteria. Results: The study showed that of 82 respondents, it was found that those working in noisy areas $<80 \mathrm{~dB}$ were 30 people, those working in 80-100 dB noisy areas were 10 people and those working in noisy areas $>100 \mathrm{~dB}$ were 42 people. Then found 30 of them have normal audiometry results, 28 NIHL, $20 \mathrm{BCHL}$ and 4 mixed people. The workers aged 20-30 years were 22 people, aged 31-40 years 17 samples, aged 41-50 years were 33 samples and aged $>51$ years were 10 people. For workers with more than 5 years of service, 76 samples and 6 samples with masa5 years of service. For workers who are not stressed 30 people, mild stress 12 people, moderate stress 18 people and severe stress 22 people.
\end{abstract}

Conclusion: The degree of noise has a significant relationship with stress. While there is no relationship between the length of service and the type of deafness. Working period also has no significant relationship to stress.

Keywords: Noisy, type of deafness, years of service, stressful

\title{
PENDAHULUAN
}

Gangguan pendengaran akibat bising (NIHL=Noise Induced Hearing Loss) sering dijumpai pada pekerja industri di negara maju maupun berkembang. Indonesia dapat disebut sebagai negara industri yang sedang berkembang, sehingga dalam upaya peningkatan pembangunan banyak menggunakan peralatan industri yang dapat menimbulkan kebisingan di lingkungan kerja. Bising dapat menyebabkan berbagai gangguan terhadap kesehatan seperti peningkatan tekanan darah, gangguan psikologis, gangguan komunikasi, gangguan keseimbangan dan gangguan pendengaran. Gangguan pendengaran adalah gangguan paling serius karena dapat menyebabkan ketulian. Ketulian dapat bersifat sementara atau menetap.(1)

Gangguan pendengaran akibat bising (Noise Induced Hearing Loss/NIHL) adalah tuli akibat terpapar oleh bising yang cukup keras dalam jangka waktu yang cukup lama dan biasanya diakibatkan oleh bising lingkungan kerja. Tuli akibat bising merupakan tuli sensorineural yang paling sering dijumpai setelah presbikusis.(2)

Data WHO mengenai angka gangguan pendengaran dan ketulian sungguh mengejutkan. Pada tahun 2000 terdapat 250 juta (4.2\%) penduduk dunia yang menderita gangguan pendengaran sedangkan tahun 2005 dijumpai 278 juta (4.2\%) penduduk dunia mengalami gangguan pendengaran. (3) 
Kebisingan yang berhubungan dengan kehilangan pendengaran telah terdaftar sebagai salah satu masalah yang paling umum pada kesehatan kerja di Amerika Serikat selama lebih dari 25 tahun. Lebih dari 28 juta warga Amerika dengan beberapa tingkat gangguan pendengaran, 10 juta diantaranya disebabkan karena terpapar bising berlebihan di tempat kerja. Biaya yang telah dikeluarkan akibat gangguan pendengaran ini diperkirakan mencapai milyaran dolar Amerika Serikat. Di Eropa, 20\% populasinya terpapar bising. Ribuan pekerja setiap tahun menderita kehilangan pendengaran tidak dapat dicegah karena tingkat kebisingan di tempat kerja yang tinggi.(4)

Berdasarkan OSHA (Occupational Health and Safety Administration) setiap tahun, sekitar 30 juta orang di Amerika Serikat yang bekerja terkena kebisingan yang berbahaya. dan lebih kurang setengahnya (75140 juta) terdapat di Asia Tenggara yang mempunyai prevalensi ketulian cukup tinggi yaitu $4.6 \%$ termasuk Indonesia, angka ini meningkat terus.(5)

Angka gangguan pendengaran dan ketulian di Indonesia cukup tinggi, data dari WHO, 50\% di Asia Tenggara termasuk Indonesia. Survei nasional 7 provinsi di Indonesia, penduduk Indonesia mengalami gangguan pendengaran sebanyak $16.8 \%$ dan ketulian $0.4 \%$.(3)

Di Indonesia penelitian tentang gangguan pendengaran akibat bising telah banyak dilakukan sejak lama. Survei yang dilakukan oleh Hendarmin pada Manufacturing Plant Pertamina dan dua pabrik es di Jakarta mendapatkan hasil terdapat gangguan pendengaran pada 50\% jumlah karyawan disertai peningkatan ambang dengar sementara sebesar 5-10 dB pada karyawan yang telah bekerja terus menerus selama 5-10 tahun.(6)

Stres yang diakibatkan kerja dapat muncul jika tuntutan lingkungan kerja melebihi kemampuan pekerja untuk mengatasi atau mengontrolnya. Sumber penyebabnya adalah gangguan stres dari pekerjaan itu sendiri, tetapi dapat juga disebabkan adanya stressor fisik, emosional dan mental.(7) Dari beberapa penelitian pada industri gas dan kompor didapatkan bahwa terdapat gangguan pendengaran tersebut meningkat pada pekerja dengan masa kerja lebih dari 9 tahun pada lingkungan bising. Pada intensitas bising $\geq 85 \mathrm{~dB}$, kemungkinan seorang pekerja dapat mengalami gangguan pendengaran setelah 5 tahun bekerja.(8)

Di PT semen Bosowa, dari 13 tempat kerja, terdapat 8 tempat yang memiliki intensitas bising $\geq 85 \mathrm{~dB}$ dan yang tertinggi mencapai 108,8 dB. Masa kerja pegawai di PT Semen Bosowa cukup bervariasi namun kebanyakan memiliki masa kerja $>5$ tahun. Dari berbagai permasalahan tersebut, maka peneliti ingin meneliti tentang hubungan kebisingan dan masa kerja terhadap jenis ketulian dan stres pada pekerja PT. Semen Tonasa. 


\section{METODE}

Penelitian ini merupakan penelitian yang menggunakan desain penelitian analitik dengan rancangan cross-sectional yang bertujuan untuk mengetahui hubungan kebisingan dan masa kerja terhadap jenis ketulian dan stress pada pekerja PT. Semen Tonasa. Penelitian ini dilaksanakan di Pabrik dan Semen Tonasa Medical Centre yang terletak di Kabupaten Pangkep. Penelitian dilakukan pada bulan Maret 2018 - Oktober 2019. Populasi dalam penelitian ini adalah semua yang terdaftar sebagai Karyawan Pekerja Bagian Pabrik PT. Semen Tonasa Pangkep yang berjumlah 108 orang. Sedangkan, sampel yang digunakan dalam penelitian ini adalah Karyawan Pekerja Bagian Pabrik PT. Semen Tonasa yang memenuhi kriteria inklusi dan kriteria eksklusi.

Penentuan besarnya sampel menggunakan rumus Slovin (apabila jumlah populasi diketahui), sebagai berikut :

$$
\mathrm{n}=\frac{\mathrm{N}}{1+\mathrm{N}(\mathrm{e})^{2}} 1+\frac{108}{108(0,10)^{2}}=52 \text { orang }
$$

Dimana : N = Jumlah Populasi, $\mathrm{n}=$ Jumlah Sampel, e = Batas toleransi kesalahan $/$ error tolerance $: 0,10$.

Metode sampel yang digunakan Purposive Sampling dan didapatkan bahwa jumlah sampel minimal adalah 52 orang dari 108 orang subyek yang termasuk dalam populasi. Dalam penelitian ini, instrumen menggunakan data primer dan data sekunder dimana data primer dengan cara wawancara melalui kuesioner dan melakukan pengukuran intensitas kebisingan dengan menggunakan Sound Level Meter. Tes ini menggunakan audiometri nada murni dimana tes dilakukan di ruangan khusus. Pada tes ini, masing-masing telinga akan dites secara terpisah, dimulai terlebih dulu pada telinga dengan kondisi baik. Pasien akan menjalani beberapa kali tes, di mana dalam setiap tes, nada yang diperdengarkan pada pasien akan semakin tinggi. Setelah itu, headphone akan dilepas, dan alat penggetar akan dipasang pada bagian belakang telinga. Pasien akan kembali diminta memberi respons jika mendengar nada.

Data sekunder diperoleh dengan cara kunjungan ke bagian Hiperkes dan Semen Tonasa Medical Centre sebagai pusat data rekam medik. Data yang diperoleh diolah menggunakan program Microsoft Excel 2013 dan dianalisis dengan menggunakan pengolah data elektronik. Analisis data menggunakan tiga cara yaitu analisis univariat yang dilakukan pada setiap variabel untuk deskripsi data, analisis bivariat untuk melihat hubungan antara dua variabel, yaitu variabel independen dan dependen, maka dilakukan uji statistik dengan menggunakan Uji Chi-square dan analisis multivariat untuk melihat hubungan yang dilakukan terhadap lebih dari dua kelompok yang diduga berhubungan. 


\section{HASIL}

Tabel 1. Karakteristik Subjek Penelitian

\begin{tabular}{cccc}
\hline Karakteristik Subjek Penelitian & $\mathbf{n}$ & $\mathbf{\%}$ \\
\hline Derajat Kebisingan Area & $<80 \mathrm{~dB}$ & 30 & 36.6 \\
Kerja & $80-100 \mathrm{~dB}$ & 10 & 12.2 \\
& $>100 \mathrm{~dB}$ & 42 & 51.2 \\
\hline Jenis Ketulian & Normal & 30 & 36.6 \\
& NIHL (Tuli Sensorineural) & 28 & 34.1 \\
& BCHL (Tuli Konduktif) & 20 & 24.4 \\
& MIXED (Tuli Campuran) & 4 & 4.9 \\
\hline Usia & $20-30$ tahun & 22 & 26.8 \\
& $31-40$ tahun & 17 & 20.7 \\
& $41-50$ tahun & 33 & 40.2 \\
& $>51$ tahun & 10 & 12.2 \\
\hline Masa Kerja & $\leq 5$ tahun & 6 & 7.3 \\
& $>5$ tahun & 76 & 92.7 \\
\hline Pengunaan APT & Ya & 71 & 86.6 \\
& Tidak & 11 & 13.4 \\
\hline Lama Paparan & $\leq 8$ Jam & 82 & 100 \\
& $>8$ Jam & 0 & 0.0 \\
\hline Stress & Tidak Stress & 30 & 36.6 \\
& Stress Ringan & 12 & 14.6 \\
& Stress Sedang & 18 & 22.0 \\
& Stress Berat & 22 & 26.8 \\
\hline Jumlah & & $\mathbf{8 2}$ & $\mathbf{1 0 0 . 0 0}$ \\
\hline
\end{tabular}

Berdasarkan data di atas menunjukkan bahwa data responden berdasarkan derajat kebisingan di area kerja terbanyak adalah pekerja yang bekerja di area pabrik dengan derajat kebisingan $>100 \mathrm{~dB}$, yaitu sebanyak 42 orang $(51,2 \%)$. Kemudian, pekerja yang bekerja di area pabrik dengan derajat kebisingan $<80 \mathrm{~dB}$, yaitu sebanyak 30 orang $(36,6 \%)$ dan pekerja yang bekerja di area pabrik dengan derajat kebisingan $80-100 \mathrm{~dB}$, yaitu sebanyak 10 orang $(12,2 \%)$.

Responden berdasarkan jenis ketulian yang terbanyak adalah kategori normal, yaitu sebanyak 30 orang $(36,6 \%)$. Kemudian NIHL, yaitu sebanyak 28 orang $(34,1 \%)$, BCHL, yaitusebanyak 20 orang $(24,4)$ dan MIXED, yaitu sebanyak 4 orang $(4,9 \%)$. 
Responden berdasarkan usia terbanyak adalah pekerja yang berumur 41-50 tahun, yaitu sebanyak 33 orang (40,2\%). Kemudian, pekerja dengan usia 20-30 tahun, yaitu sebanyak 22 orang (26,8\%), pekerja dengan usia 31-40 tahun, yaitu sebanyak 17 orang (20,7\%) dan pekerja dengan usia $>51$ tahun, yaitu sebanyak 10 orang $(12,2 \%)$.

Responden berdasarkan masa kerja terbanyak adalah pekerja yang bekerja selama $>5$ tahun, yaitu sebanyak 76 orang $(92,7 \%)$. Kemudian, pekerja yang bekerja selama $\leq 5$ tahun, yaitu sebanyak 6 orang (7,3\%).

Responden yang menggunakan APT yang terbanyak sebanyak 71 orang $(86,6 \%)$ sedangkan yang tidak menggunakan sebanyak 11 orang $(13,4 \%)$. Berdasarkan lama paparan yang terbanyak adalah $\leq 8$ jam yaitu sebanyak 82 orang $(100 \%)$ sedangkan $>8$ jam tidak ada $(0.0 \%)$. Berdasarkan stres pada pekerja yang terbanyak adalah tidak stres, yaitu sebanyak 30 orang (36,6\%), kemudian stres berat yaitu sebanyak 22 orang $(26,8 \%)$, stres sedang yaitu sebanyak 18 orang $(22,0 \%)$ dan stres ringan, yaitu sebanyak 12 orang $(14,6 \%)$.

Analisa Hubungan Derajat Kebisingan Area Kerja Terhadap Jenis Ketulian pada Pekerja PT. Semen Tonasa Pangkep

Tabel 2. Hubungan Derajat Kebisingan Area Kerja Terhadap Jenis Ketulian

\begin{tabular}{|c|c|c|c|c|c|c|c|c|c|c|c|}
\hline \multicolumn{3}{|c|}{ Derajat Kebisingan } & \multicolumn{8}{|c|}{ Jenis Ketulian } & \multirow{3}{*}{$p$} \\
\hline & (n) & $(\%)$ & $\mathbf{n}$ & $(\%)$ & $\mathbf{n}$ & $(\%)$ & $\mathbf{n}$ & $(\%)$ & \multicolumn{2}{|c|}{ Total } & \\
\hline & \multicolumn{2}{|c|}{ NORMAL } & \multicolumn{2}{|c|}{ NIHL } & \multicolumn{2}{|c|}{ BCHL } & \multicolumn{2}{|c|}{ MIX } & $\mathbf{n}$ & $(\%)$ & \\
\hline$<85 \mathrm{~dB}$ & 30 & 37 & 0 & 0 & 0 & 0 & 0 & 0 & 30 & 37 & 000 \\
\hline$>85 \mathrm{~dB}$ & 0 & 0 & 28 & 33.9 & 20 & 24.3 & 4 & 4.9 & 52 & 63 & .000 \\
\hline Total & 30 & 37 & 28 & 33.9 & 20 & 24.3 & 4 & 4.9 & 82 & 100 & \\
\hline
\end{tabular}

Berdasarkan tabel 2 menunjukkan hasil uji statistik (Chi-Square) dengan nilai p $(0,000)$. Artinya, derajat kebisingan mempengaruhi jenis ketulian. Dengan kata lain, terdapat hubungan yang signifikan antara derajat kebisingan dengan jenis ketulian.

\section{Analisa Hubungan Derajat Kebisingan Area Kerja Terhadap Stres pada Pekerja PT. Semen Tonasa Pangkep}

Tabel 3. Hubungan Derajat Kebisingan Area Kerja Terhadap Stres

\begin{tabular}{|c|c|c|c|c|c|c|c|c|c|c|c|}
\hline \multicolumn{3}{|c|}{ Derajat Kebisingan } & \multicolumn{6}{|c|}{ Jenis Ketulian } & & & \multirow{3}{*}{$p$} \\
\hline & (n) & $(\%)$ & $\mathbf{n}$ & $(\%)$ & $\mathbf{n}$ & $(\%)$ & $\mathbf{n}$ & $(\%)$ & $\mathbf{n}$ & $(\%)$ & \\
\hline & \multicolumn{2}{|c|}{ TIDAK } & \multicolumn{2}{|c|}{ RINGAN } & \multicolumn{2}{|c|}{ SEDANG } & \multicolumn{2}{|c|}{ BERAT } & \multicolumn{2}{|c|}{ TOTAL } & \\
\hline$<85 \mathrm{~dB}$ & 30 & 37 & 0 & 0 & 0 & 0 & 0 & 0 & 30 & 37 & \multirow{2}{*}{0.000} \\
\hline$>85 \mathrm{~dB}$ & 0 & 0 & 12 & 14.5 & 18 & 21.8 & 22 & 26.7 & 52 & 63 & \\
\hline Total & 30 & 37 & 12 & 14.5 & 18 & 21.8 & 22 & 26.7 & 82 & 100 & \\
\hline
\end{tabular}


Berdasarkan tabel 3 menunjukkan hasil uji statistik (Chi-Square) dengan nilai $p(0,000)$. Artinya, derajat kebisingan berhubungan terhadap stres. Dengan kata lain, terdapat hubungan yang signifikan antara derajat kebisingan terhadap stres.

\section{Analisa Hubungan Masa Kerja Terhadap Jenis Ketulian pada Pekerja}

Tabel 4. Hubungan Masa Kerja Terhadap Jenis Ketulian

\begin{tabular}{|c|c|c|c|c|c|c|c|c|c|c|c|}
\hline \multicolumn{3}{|c|}{ Masa Kerja } & \multicolumn{6}{|c|}{ Jenis Ketulian } & \multirow[b]{2}{*}{$\mathbf{n}$} & \multirow[b]{2}{*}{$(\%)$} & \multirow{3}{*}{$p$} \\
\hline & (n) & $(\%)$ & $\mathbf{n}$ & $(\%)$ & $\mathbf{n}$ & $(\%)$ & $\mathbf{n}$ & $(\%)$ & & & \\
\hline & \multicolumn{2}{|c|}{ NORMAL } & \multicolumn{2}{|c|}{ NIHL } & \multicolumn{2}{|c|}{ BCHL } & \multicolumn{2}{|c|}{ MIX } & \multicolumn{2}{|c|}{ TOTAL } & \\
\hline$\leq 5$ Tahun & 3 & 3.7 & 2 & 2.4 & 0 & 0 & 1 & 1.2 & 6 & 7.3 & \multirow{2}{*}{0.291} \\
\hline$>5$ Tahun & 27 & 33 & 26 & 32 & 20 & 24.3 & 3 & 3.7 & 76 & 92.7 & \\
\hline Total & 30 & 36.7 & 28 & 34.4 & 20 & 24.3 & 4 & 4.9 & 82 & 100 & \\
\hline
\end{tabular}

Berdasarkan tabel 4 menunjukkan hasil uji statistik (Chi-Square) dengan nilai p (0,291). Artinya, masa kerja sampel tidak mempengaruhi jenis ketulian. Dengan kata lain, tidak terdapat hubungan yang signifikan antara masa kerja dengan jenis ketulian.

\section{Analisa Hubungan Masa Kerja Terhadap Stres pada Pekerja}

Tabel 5. Hubungan Masa Kerja terhadap Stres

\begin{tabular}{|c|c|c|c|c|c|c|c|c|c|c|c|}
\hline \multicolumn{3}{|c|}{ Masa Kerja } & \multicolumn{6}{|c|}{ Jenis Ketulian } & & & \multirow{3}{*}{$p$} \\
\hline & (n) & $(\%)$ & $\mathbf{n}$ & $(\%)$ & $\mathbf{n}$ & $(\%)$ & $\mathbf{n}$ & $(\%)$ & $\mathbf{n}$ & $(\%)$ & \\
\hline & \multicolumn{2}{|c|}{ TIDAK } & \multicolumn{2}{|c|}{ RINGAN } & \multicolumn{2}{|c|}{ SEDANG } & \multicolumn{2}{|c|}{ BERAT } & \multicolumn{2}{|c|}{ TOTAL } & \\
\hline$<5$ Tahun & 3 & 3.7 & 1 & 1.2 & 1 & 1.2 & 1 & 1.2 & 6 & 7.3 & 0881 \\
\hline$>5$ Tahun & 27 & 33 & 11 & 13.4 & 17 & 21 & 21 & 27.2 & 76 & 92.7 & 0.881 \\
\hline Total & 30 & 36.7 & 12 & 14.6 & 18 & 22.2 & 22 & 28.4 & 82 & 100 & \\
\hline
\end{tabular}

Berdasarkan tabel 5 diketahui bahwa masa kerja baru ( $\leq 5$ tahun) (7,3\%) dan masa kerja lama ( $>5$ tahun) $(92,7 \%)$. Hasil analisis diperoleh $p$-value $0,881 \geq 0,05$ sehingga tidak ada hubungan antara masa kerja dengan stres kerja.

\section{Analisis Regresi Linear Berganda Stres}

Tabel 6. Hasil Analisis Regresi Linier Berganda

\begin{tabular}{cccccc}
\hline \multirow{2}{*}{ Model } & \multicolumn{2}{c}{$\begin{array}{c}\text { Unstandardized Coeffi- } \\
\text { cients }\end{array}$} & $\begin{array}{c}\text { Standardized } \\
\text { Coefficients }\end{array}$ & t & \multirow{2}{*}{ Sig. } \\
\cline { 2 - 5 } & $\mathbf{B}$ & Std. Error & Beta & & \\
\hline (Constant) & -19.322 & 2.491 & & -7.758 & 0.000 \\
Masa Kerja & 0.144 & 0.052 & 0.157 & 2.748 & 0.007 \\
Kebisingan & 0.381 & 0.026 & 0.833 & 14.545 & 0.000 \\
\hline
\end{tabular}


Berdasarkan hasil tabel analisis regresi dapat dijelaskan besarnya pengaruh masing-masing variabel independen terhadap variabel dependen adalah sebagai berikut:

Nilai koefisien regresi untuk variabel masa kerja yaitu 0.144 (jika skor masa kerja bertambah 1 poin maka skor stres juga akan bertambah 0.144 poin atau sebaliknya). Hal ini berarti bahwa masa kerja berpengaruh positif terhadap stres yang berarti semakin tinggi skor masa kerja maka skor stres juga semakin tinggi begitupun sebaliknya.

Nilai koefisien regresi untuk variabel kebisingan yaitu 0.381 (jika skor kebisingan bertambah 1 poin maka skor stres juga akan bertambah sebesar 0.381 poin atau sebaliknya). Hal ini berarti bahwa kebisingan berpengaruh positif terhadap stres yang berarti semakin tinggi skor kebisingan maka skor stres juga semakin tinggi begitupun sebaliknya.

\section{PEMBAHASAN}

\section{Analisa Hubungan Derajat Kebisingan Area Kerja Terhadap Stres pada Pekerja PT. Semen Tonasa Pangkep}

Berdasarkan hasil penelitian yang telah dilakukan peneliti pada derajat kebisingan dan jenis ketulian, menunjukkan Hasil uji statistik (Chi-Square) dengan nilai $p(0,000)$. bahwa terdapat hubungan yang signifikan antara derajat kebisingan dan jenis ketulian. Hal ini menunjukkan bahwa lingkungan kerja berpotensi menyebabkan pekerja mengalami ketulian. Terdapatnya hubungan antara kebisingan dengan jenis ketulian yang dialami pekerja disebabkan karena kondisi lingkungan kerja yang sumber kebisingannya belum dikendalikan secara maksimal.

Penelitian yang dilakukan oleh Rezqi \& Widowati (2017) menunjukkan bahwa intensitas kebisingan tinggi berisiko 2,779 kali lebih besar $(\mathrm{p}=0,034)$ dalam menimbulkan dengan gangguan pendengaran.(9) Adapun penelitian lainnyanya yang menyimpulkan bahwa kebisingan yang ditimbulkan oleh mesin kereta ( $p$-value $<0,05)$ secara signifikan berhubungan dengan Noise Induced Hearing Loss. Beberapa penelitian tersebut mendukung bahwa kebisingan baik yang bersifat stastis maupun dinamis berhubungan dengan gangguan pendengaran. (10)

Kebisingan yang memiliki intensitas tinggi dan berlangsung cukup lama akan dapat merangsang perubahan metabolisme yang terdapat pada reseptor pendengaran. Sehingga dapat mengakibatkan terjadi kerusakan pada sel-sel rambut organ korti. Kerusakan sel-sel rambut reseptor pada organ korti itu yang bersifat degeneratif sehingga dapat mengakibatkan berkurangnya pendengaran.(11) Kerusakan total pada sel-sel rambut dari organ korti itu akan berdampak pada hilangnya fungsi pendengaran. Namun, pada penelitian terbaru menunjukkan bahwa sel-sel rambut bukanlah elemen yang paling rentan pada telinga bagian dalam, melainkan sinapsis antara sel-sel rambut dan terminal saraf koklea.(12) Gangguan pendengaran dapat disebabkan oleh paparan tunggal terhadap suara yang bersifat impulsif seperti ledakan atau oleh paparan jangka panjang.(13) 


\section{Hubungan Derajat Kebisingan Area Kerja Terhadap Stres}

Hasil penelitian menunjukkan bahwa sebagian besar area pabrik bising (76,0\%). Hasil uji Chi-Square diperoleh bahwa ada hubungan yang signifikan antara kebisingan dengan stres kerja. Pekerja yang memiliki area bising cenderung mengalami stres kerja dibanding pekerja yang tidak memiliki area bising. Hal ini dikarenakan suara bising yang ada di area produksi pabrik sebesar $85 \mathrm{~dB}$ yang mengakibatkan pekerja sulit berkonsentrasi saat bekerja, tidak nyaman bekerja dari alat-alat kerja dan mudah terpancing emosi.(14) Berdasarkan hasil analisis bivariat bahwa ada pengaruh derajat kebisingan terhadap stres kerja di area pabrik PT. Semen Tonasa. Pekerja yang bekerja di area kerja dengan derajat kebisingan tinggi berpeluang untuk stres sebesar 24 kali lebih besar dibanding dengan pekerja yang tidak bekerja di area kerja dengan derajat kebisingan tinggi memiliki kebisingan.(15)

Hal ini sejalan dengan penelitian Ali (2020) di PT. Roda Teknindo Pura Jaya Bengkulu Utara bahwa dari hasil pengukuran kebisingan tertinggi diketahui rata-rata 92,2 $\mathrm{dB}$ dan frekuensi stres kerja lebih dari sebagian 18 (51,4\%) pekerja mengalami stres kerja ringan. (16)

Sejalan dengan penelitian Yusmardiansyah \& Zahra (2019) yang berjudul Hubungan Antara Kebisingan dengan Stres Kerja Pada Pekerja BagianProduksi PT. Mitra Bumi hubungan antara kebisingan dengan stres kerja pada pekerja dengan $p$ value 0,001.(17) Namun berbeda dengan penelitian yang dilakukan oleh Amir (2019) bahwa tidak terdapat hubungan antara kebisingan dengan stres kerja pada pekerja bagian body rangka PT. X. Hal ini disebabkan oleh karena pada bagian body rangka pengukuran kebisingan sebagian besar berada di bawah Nilai Ambang Batas. Pekerja di ijinkan keluar pabrik saat jam istiharat. Pekerja memperoleh waktu istirahat selama 60 menit dari 8 jam kerja. Biasanya waktu tersebut di pergunakan untuk istirahat, ibadah dan makan. Beberapa pekerja menggunakan waktu istirahat semaksimal mungkin untuk kembali ke tempat tinggal mereka yang rata-rata dekat dengan pabrik dan juga bersenda gurau dengan teman kerja sehingga hal tersebut dapat menenangkan kembali pikiran pekerja setelah melakukan pekerjaan. Dinding kerja yang berbahan semen kurang mampu menyerap sumber bising yang ada diarea kerja, maka dari itu dengan menambahkan material yang bersifat absorber guna menyerap bunyi bising agar kebisingan dapat berkurang. Serta melakukan pengawasan yang rutin pada pekerja yang tidak mematuhi aturan dengan tidak menggunakan APD (Ear plug) saat melakukan pekerjaan. (18)

\section{Hubungan Masa Kerja Terhadap Jenis Ketulian}

Berdasarkan hasil penelitian ini pada masa kerja dan jenis ketulian tidak terdapat hubungan yang signifikan antara masa kerja dan jenis ketulian. Penelitian ini tidak sejalan dengan penelitian yang dilakukan oleh Lazuardi (2020) bahwa terdapat hubungan antara masa kerja dengan gangguan pendengaran pada karyawan di PT. ICSM Desa Liang Anggang. Adanya hubungan masa kerja dengan penurunan nilai ambang dengar pada pekerja yang terpapar bising. (19) Namun, hasil penelitian ini sejalan dengan penelitian Hidayat dkk (2019) yang melakukan penelitian di tempat yang sama sebelumnya bahwa masa kerja dapat tidak berhubungan dengan jenis ketulian karena adanya kebijakan PT. Semen Tonasa yang telah menerapkan sistem mutasi bagi pekerja dalam jangka waktu tertentu, namun waktu dan jumlah pekerja yang dimutasi masih sangat terbatas. 
Selain sistem mutasi dari perusahaan tersebut, pekerja yang telah melakukan medical check up dan memiliki hasil abnormal dapat meminta untuk di mutasi dan diproses untuk pindah ke unit kerja lainnya. Efek samping dari lama masa seseorang bekerja dapat berakibat pada ketulian permanen, dimana jika seorang pekerja penderita ketulian sementara (Temporary Threshold Shift) kemudian terpajan bising kembali sebelum pemulihan, maka akan terjadi akumulasi sisa ketulian dan jika hal ini berlangsung secara berulang dan menahun, sifat ketulian tersebut akan berubah menjadi permanen.(20)

\section{Hubungan Masa Kerja Terhadap Stres}

Berdasarkan hasil penelitian didapatkan bahwa sebagian besar responden memiliki masa kerja $>5$ tahun yakni sebanyak 76 pekerja (92,7\%), dengan masa kerja paling pendek adalah 2 tahun sedangkan masa kerja paling lama adalah 37 tahun. Masa kerja yang lebih lama erat kaitannya dengan pengalaman dan pemahaman dikarenakan sudah beradaptasi antara responden atau tenaga kerja dengan pekerjaannya. Hasil penelitian ini menunjukkan masa kerja tidak mempengaruhi stres. Dengan kata lain, tidak terdapat hubungan yang signifikan antara masa kerja dengan stres.

Berbeda dengan penelitian Aulia (2019) di PT Angkasa Pura I Bandar Udara Internasional Sam Ratulangi Manado yang menyatakan bahwa terdapat korelasi bermakna dari masa kerja dengan stres kerja. Nilai koefisien korelasi yaitu -0,411 menyatakan adanya korelasi negatif dengan kekuatan hubungan sedang. Semakin lama masa kerja individu tersebut, semakin rendah stres kerja. Sebaliknya masa kerja yang relatif singkat mempunyai stres kerja yang semakin tinggi. (21) 


\section{DAFTAR PUSTAKA}

1. Lintong F. Gangguan pendengaran akibat bising. J Biomedik. 2013;1(2):81-86.

2. Tjan H, Lintong F, Supit W. Efek bising mesin elektronika terhadap gangguan fungsi pendengaran pada pekerja di kecamatan sario kota manado, sulawesi utara. J e-Biomedik. 2013;1(1):34-39.

3. Fritschi L, Brown AL, Kim R, Schwela D, Kephalopoulos S. Burden of disease from environmental noise: Quantification of healthy life years lost in Europe. World Health Organization. 2011.

4. American Hearing Research Foundation. Noise induced hearing loss. 2012.

5. OSHA. Occupational noise exposure. United States Department Of Labor. 2012.

6. Susanto A. Dampak kebisingan terhadap kesehatan lingkungan. [Internet]. 2006. Available from: http:/ www.hseclubindonesia.wordpress.com/2006/10/13/kebisinganserta-pengaruhnya- terhadap-kesehatanlingkungan/.

7. Gobel RS, Rattu JAM, Akili RH. Faktor-faktor yang berhubungan dengan stres kerja pada perawat di ruang ICU Dan UGD RSUD Datoe Bingkang Kabupaten Bolaang Mangondow. J Kesehat. 2013;10(1):17.

8. Eryani YM. Hubungan intensitas kebisingan, durasi papara, dan penggunaan alat pelindung diri dengan gangguan pendengaran akibat bising pada karyawan PT. Bukit Asam (Persero) Tbk Bandarlampung. J Chem Inf Model. 2013;53(9):1689-99.

9. Rezqi Septiana N, Widowati E. Gangguan Pendengaran Akibat Bising. 2017;1(1):73-82. Available from: http://journal.unnes.ac.id/sju/index.php/higeia.

10. Saxena A. Noise Induced Hearing Loss in Indian Railway Loco Pilots: Are We Aware? Otolaryngol Open J. 2018;4(2):18-21.

11. Moore DR, Edmondson-Jones M, Dawes P, Fortnum H, McCormack A, Pierzycki RH, et al. Relation between speech-in-noise threshold, hearing loss and cognition from 40-69 years of age. PLoS One. 2014;9(9):1-10.

12. Liberman MC, Epstein MJ, Cleveland SS, Wang H, Maison SF. Toward a differential diagnosis of hidden hearing loss in humans. PLoS One. 2016;11(9):1-15.

13. Basner M, Babisch W, Davis A, Brink M, Clark C, Janssen S, et al. Auditory and non-auditory effects of noise on health. Lancet. 2014;383(9925):1325-32.

14. Adriyani R, Nawawinwtu ED. Stress Akibat Kerja pada Tenaga Kerja yang Terpapar Bising. Indones J Public Heal. 2007;4(2):59-63. Malaysia. Malaysian J Community Heal. 2010;16(2):66-74. 
15. A study of occupational stress and coping strategies among correctional officers in Kedah, Malaysia. Malaysian J Community Heal. 2010;16(2):66-74.

16. Ali H, Mulyati S. Analysis of engine noise level of stone crusher and work stress year 2018. 2020;8(1):3742.

17. Yusmardiansyah, Zhara G. Hubungan kebisingan dengan stres kerja pada perkerja bagian produksi di pt mitra bumi. PREPOTIF J Kesehat Masy. 2019;3:23-30.

18. Amir J, Wahyuni I, Ekawati. Hubungan Kebisingan, Kelelahan Kerja Dan Beban Kerja Mental Terhadap Stres Kerja Pada Pekerja Bagian Body Rangka PT. X. J Fak Kesehat Masy [Internet]. 2019;1. Available from: file://C:/Users/User/Downloads/fvm939e.pdf

19. Lazuardi R. Hubungan masa kerja sikap dan penggunaan apt dengan gangguan pendengaran di pt. icsm desa liang anggang kecamatan bati-bati kabupaten tanah laut kalimantan selatan. 2020; Available from: http://eprints.uniska-bjm.ac.id/id/eprint/749

20. Hidayat, Purnawati K, M ASD. Faktor risiko gangguan pendengaran pada pekerja di bagian produksi pt. Semen tonasa kab pangkep. Sulolipu Media Komun Sivitas Akad dan Masy. 2019;19(2).

21. Aulia L, Kawatu PAT, Langi FLFG. Hubungan antara beban kerja dan masa kerja dengan stres kerja pada Security Check Point di PT Angkasa Pura I Bandar Udara Internasional Sam Ratulangi Manado. Med Scope J. 2019;1(1):16-20 